\title{
Reed canary grass - observations of effects on crop stand and fibre quality caused by infestation of Epicalamus phalaridis
}

\author{
Sven Hellqvist \\ Department of Agricultural Research for Northern Sweden, Swedish University of Agricultural Sciences (SLU), \\ PO Box 4097, S-904 03 Umeå, Sweden, e-mail: sven.hellqvist@njv.slu.se
}

Michael Finell, Staffan Landström

The unit of Biomass Technology and Chemistry, Swedish University of Agricultural Sciences (SLU),

PO Box 4097, S-904 03 Umeå, Sweden

\begin{abstract}
A severe infestation of the gall midge Epicalamus phalaridis (Diptera: Cecidomyiidae) occurred in a field of reed canary grass, Phalaris arundinacea, in northern Sweden. The midge species has potential to become a serious pest on Phalaris grown for bioenergy or fibre production. Larvae of the midge feed beneath leaf sheaths and the crop lodges in late summer. Details are given on the biology of the midge. In the infested field, population densities of the midge were very high during three consecutive years. The crop was weakened and the occurrence of weeds increased. The dry matter yields declined markedly and were after three years of midge-attack about $50 \%$ of the average yield in the preceding years. The yield dropped comparatively more when the crop was harvested in the spring as opposed to harvest in late autumn and more at a nitrogen fertilisation at $100 \mathrm{~kg}$ compared to $200 \mathrm{~kg} \mathrm{~N} \mathrm{ha}{ }^{-1}$ per year. The effect of midge attack on fibre quality was studied. The fibre properties of midge-infested parts of internodes were poor, but as midge-damaged parts are brittle, they could probably be sorted out in a fractionation process. Undamaged parts of infested internodes had the same fibre properties as those from an uninfested crop.
\end{abstract}

Key words: Epicalamus phalaridis, gall midge Cecidomyiidae, Phalaris arundinacea, fibre plants, shoots, harvesting time, fertilizers, pulps, fibre quality

\section{Introduction}

Reed canary grass, Phalaris arundinacea L., has since long been grown as a fodder crop and in recent years also as a crop for bioenergy production (Landström et al. 1996, Hadders and
Olsson 1997). Reed canary grass (RCG) also has potential as a short-fibre source for the pulp industry (Olsson et al. 1994, Paavilainen et al. 1999, Saijonkari-Pahkala 2001).

The impact of insect pests on yield and quality of RCG has achieved little attention Vasarainen et al. (1999) observed numerous leaf- 
Hellqvist, S. et al. Reed canary grass and effects of gall midge infestation

hoppers, especially Balclutha punctata (F.), infesting panicles of RCG in cultivated fields in Finland. The aphid Rhopalomyzus lonicerae Sieb. feeds on the leaves and has occurred at high population densities in some places in certain years, both in Finland (Vasarainen et al. 1999) and in Sweden (S. Hellqvist, unpublished). The impact of both these species on RCG yield is not known. Two gall midge species, both feeding beneath leaf sheaths of RCG, have been reported to seriously damage RCG stands: Mayetiola phalaris Barnes in Germany (Tomaszewski 1931, Barnes 1946) and Epicalamus phalaridis Sylvén in Sweden (Sylvén et al. 1997). The latter species is the focus for this report.

The following details of Epicalamus phalaridis biology summarise observations made in the field (Sylvén et al. 1997, S. Hellqvist, unpublished). Adults emerge in early summer (in northern Sweden in mid to late June), before the panicles on fertile RCG shoots become visible. Adults are ephemeral and have probably low capacity for long range dispersal. Females oviposit preferentially at the base of the uppermost fully expanded leaf on the shoots. Eggs are deposited in dense clusters, usually comprising 40120 eggs. Large females have a total egg load of about 300-400 eggs.

Upon hatching, the young larvae move beneath the sheath of the leaf on which the eggs were laid, to feed gregariously on the lower part of the stem internode. When full-grown (in northern Sweden in August), the larvae leave the shoots for overwintering in cocoons on the ground. However, most often the larvae remain inside the leaf sheath until the shoot bends and the leaf sheath splits open. In northern Sweden there is one complete generation a year of E. phalaridis, but after the unusually warm summer of 1997, oviposition of a partial second generation was observed in late August.

The developing larvae cause no typical galls on the host, but attack by midge-larvae interferes with the incorporation of cellulose in the cell walls. At the site of larval attack, cell walls of the stem remain thin and the shoot easily bends at that point. At high infestation level, the infested crop lodge in late summer.

E. phalaridis is so far only known from northern Sweden, from latitudes $63^{\circ}$ to $66^{\circ} \mathrm{N}$. Here, it appears to be fairly common on RCG growing on river banks and sea shores. The species may, however, have a much larger distribution (Sylvén et al. 1997). E. phalaridis was first noticed in 1996, in an experimental field in Vojakkala $\left(65^{\circ} 52^{\prime} \mathrm{N}, 24^{\circ} 05^{\prime} \mathrm{E}\right)$ in the Torne river basin, northern Sweden. In this field, a very high infestation level was noticed (Sylvén et al. 1997). A slight reduction in the yield of RCG harvested in August was noticed, but the impact of midge attack on dry matter production was considered to be rather low. However, it was speculated that the effect of infestation on the yield might be greater if RCG was harvested in the spring (Sylvén et al. 1997), which is preferable when RCG is used as an industrial crop (Landström et al. 1996, Burvall 1997, SaijonkariPahkala 2001).

In an attempt to answer the question whether infestation by $E$. phalaridis affects the yield of RCG, we here present yield data from this particular field. Data are presented from both the years before midge attack was noticed (19931995) as well as from three consecutive years (1996-1998) with very high infestation levels. For comparison we present data on yields from another field in Vojakkala, with only slight infestation of E. phalaridis. The effect of midge damage on fibre quality was also studied.

\section{Material and methods}

\section{Experimental fieds}

Data on infestation by E. phalaridis and dry matter yields are presented from two separate experimental fields (called V1 and V2), situated $1 \mathrm{~km}$ apart, in Vojakkala. The soil type at both fields was fine sand with moderate humus content. The length of the vegetation season (number 
Vol. 12 (2003): 49-56.

of days with daily mean temperature $>+5^{\circ} \mathrm{C}$ ) is on average 135 days at Vojakkala (Landström et al. 1982).

$V 1$. The objective for this experiment was to study the sustainability and yielding capacity of RCG. The experimental plan comprised four harvest times (main-plot factor) combined with four fertilisation treatments (sub-plot factor) in a split-plot design with 3 replicates. The experimental plots were sown (row space $12 \mathrm{~cm}$ ) in the spring 1990 with $16 \mathrm{~kg}$ seeds per ha of 'Palaton'. The size of the fertilised and harvested plots was equal, ca $20 \mathrm{~m}^{2}$. Plots were harvested once a year since 1991. Harvests were performed with a forage plot harvester (Haldrup 1500, Denmark).

Yield data for the years 1993-1998 are presented from a subset of this field experiment: two harvest times combined with two nitrogen fertilisation treatments. The harvest times were: autumn, when growth of the crop had ceased for the season and spring, when the soil was dry enough for bearing capacity and when the senescent crop was dry (water content below 20\%). Harvest dates depended on actual weather conditions. Autumn harvests were usually performed in October and spring harvests in late May. Nitrogen fertilisation treatments were $100 \mathrm{~kg}$ and $200 \mathrm{~kg} \mathrm{~N}$ per ha and year. Both treatments received potassium at the dose $50 \mathrm{~kg} \mathrm{~K}$ per ha and year. The crops were fertilised in the spring. At harvest time, the proportion of RCG in the harvested material was visually estimated (data presented only for autumn-harvested plots).

$V 2$. The objective for this experiment was to study the effect of different fertilisation regimes in spring-harvested RCG. The experimental plan comprised five levels of nitrogen fertilisation combined with three levels of potassium and phosphorous in a split-plot design with two replicates. It was established in 1995, in an old RCG ley. Plot size and variety were the same as in V1. For comparison with V1, we chose plots that received the same level of nitrogen fertilisation as in that experiment. Data presented on dry matter yields are the average of yields from plots receiving $100 \mathrm{~kg} \mathrm{~N} \mathrm{~kg}^{-1}$ and either $5 \mathrm{~kg} \mathrm{P}$ and $25 \mathrm{~kg} \mathrm{~K}$ or $10 \mathrm{~kg} \mathrm{P}$ and $50 \mathrm{~kg} \mathrm{~K} \mathrm{ha}{ }^{-1}$ each year (altogether 4 plots).

Yield data for separate years refer always to vegetation years; crops harvested in the spring were harvested the year after the vegetation year. Data on dry matter yields are presented as relative yields. For each plot, the average yield for the years 1993-1995 was calculated and the plotyields for each of the years 1993-1998 were then divided with that value and multiplied by 100 . Relative yields from V1 were subjected to factorial analysis of variance to see whether the effect of midge-infestation was affected by harvest time and nitrogen fertilisation.

\section{Field sampling}

In the years 1996-1998, degree of midge-infestation was estimated in the two experimental fields. V1 was the field where infestation by the gall midge was first noticed. In both fields, samples were taken in spring-harvested plots. Sampling dates were 10 September 1996, 21 August 1997 and 14 August 1998.

In randomly selected small sampling plots $\left(0.02 \mathrm{~m}^{2}\right)$, all shoots were cut at ground level. The length of the shoots (from ground level to tip of panicle or the uppermost leaf) was measured and every internode on the shoots was examined for symptoms of infestation by midge larvae. Fertile shoots (with panicle) and sterile shoots were analysed separately. In V1, samples were taken from two fertilisation treatments, receiving 100 and $200 \mathrm{~kg} \mathrm{~N} \mathrm{ha}^{-1}$ per year, respectively. From each treatment, samples were taken in two replicated plots. In each plot, four subsamples were taken that were joined to one sample for the plot. For each plot, the average shoot length, the percentage of midge-infested shoots and the average number of midge-infested internodes per shoot, were calculated. Correlation coefficients were calculated to test whether the length of fertile shoots was related to the number of midge infested internodes. Separate coefficients were calculated for different years.

In V2, samples were taken from two fertili- 
Hellqvist, S. et al. Reed canary grass and effects of gall midge infestation

sation treatments, both receiving $100 \mathrm{~kg} \mathrm{~N} \mathrm{ha}^{-1}$ per year, but differing in $\mathrm{P}$ and $\mathrm{K}$ fertilisation (see above under "Experimental fields"). Sampling and calculations were as in V1, except that in 1998 only two subsamples were taken in each treatment plot.

In 1997, sampling for number of midge larvae on infested internodes was made on two occasions in V1; on 7 July (shortly after hatching) and on 21 August (when most larvae were fullgrown). At the first sampling date, 21 infested internodes on fertile shoots were examined and in August, 24 internodes on fertile shoots and 13 internodes on sterile shoots. Internodes to be examined were not broken and had closed leaf sheaths.

\section{Fibre quality}

Samples for analysis of fibre quality were taken in Vojakkala in May 1997. RCG from the field severely infested by E. phalaridis (V1) was compared with RCG of the same variety ('Palaton') from another field in the vicinity, but with only very slight gall midge infestation. From each field, three random samples (each comprising about $70 \mathrm{~g}$ ) were taken of the senescent crops, cut at ground level.

The samples were first sorted in two fractions: "internodes" and "reject" (nodes, leaves, leaf sheaths and panicles). The internode-fraction from the uninfested crop (I) was not fractionated further. The internode-fraction from the midge-infested crop was separated further in four fractions: II. Uninfested internodes; III. Undamaged parts of midge-infested internodes; IV. Severely damaged parts of infested internodes; V. Transitional zone between damaged and undamaged parts of midge-infested internodes. The material in the respective fraction was weighed.

For the fibre analysis, samples (about $5 \mathrm{~g}$ per sample) were treated with a mixture of 50 vol- $\%$ concentrated acetic acid and 50 vol- $\%$ concentrated hydrogen peroxide for $18 \mathrm{~h}$ at $65^{\circ} \mathrm{C}$ to separate the fibres. After washing and disintegration, the samples were analysed for pulp yield. The fibre characteristics were measured on a Kajaani FS-200 fibre analyser.

\section{Results}

\section{Field sampling}

There was no clear difference in level of midgeinfestation between fertilisation treatments in the respective experimental field. Therefore, only data on the average infestation levels and shoot lengths from the respective fields are presented (Table 1). In V1, the infestation level remained at a very high level throughout the period, but with an indication of a peak in 1997. In all three years, most fertile shoots had lodged at the end of August, but still growing sterile shoots emerged through the layer of broken shoots. Most fertile shoots were infested on several internodes and in 1997, as many as five were infested on some shoots. On examined infested internodes in July 1997, the average number of midge-larvae was 1134 (range 5-3070; SEM = $199 ; n=21)$ per internode. In August, the average number of larvae was 207 (range 1-724; $\mathrm{SEM}=40 ; \mathrm{n}=24$ ) on fertile shoots and 47 (range 7-185; SEM = 14; $\mathrm{n}=13$ ) per infested internode on sterile shoots.

In V2, only few shoots were midge-infested in 1996 and 1997 but the infestation level increased somewhat in 1998 (Table 1). In that year, midge-infested shoots were found in all sampled plots but the percentage of infested fertile shoots varied from 7 to $50 \%$. Almost no lodging was observed in either year.

In all three years, fertile shoots were on average shorter in the severely midge-infested field than in the less infested field (Table 1). The shoots were especially short in 1997, when the midge-infestation level peaked. Correlation analysis of shoots from V1 showed that there was a weakly negative relation between number of midge-infested internodes and shoot length. The correlation coefficients ( $r$ ) were $-0.22,-0.16$ and 
Vol. 12 (2003): 49-56.

Table 1. Infestation by Epicalamus phalaridis on fertile and sterile shoots of reed canary grass, in two separate experimental fields at Vojakkala, in the years 1996-1998. Mean values from four plots per field ( \pm SEM).

\begin{tabular}{|c|c|c|c|c|c|c|c|}
\hline \multirow{2}{*}{$\begin{array}{l}\text { Experi- } \\
\text { mental field } \\
\text { Year }\end{array}$} & \multicolumn{4}{|c|}{ Fertile shoots } & \multicolumn{3}{|c|}{ Sterile shoots } \\
\hline & $\begin{array}{c}\text { Percentage } \\
\text { infested }\end{array}$ & $\begin{array}{l}\text { Infested } \\
\text { internodes } \\
\text { /shoot, nr }\end{array}$ & $\begin{array}{l}\text { Average } \\
\text { shoot } \\
\text { length, cm }\end{array}$ & $\begin{array}{c}\text { Examined } \\
\text { shoots, total } \\
\text { number }\end{array}$ & $\begin{array}{c}\text { Percentage } \\
\text { infested }\end{array}$ & $\begin{array}{c}\text { Infested } \\
\text { internodes } \\
\text { /shoot, nr }\end{array}$ & $\begin{array}{r}\text { Examined } \\
\text { shoots, tota } \\
\text { number }\end{array}$ \\
\hline \multicolumn{8}{|l|}{ V1 } \\
\hline 1996 & $100 \quad( \pm 0)$ & $2.4 \quad( \pm 0.1)$ & $141( \pm 8.3)$ & 42 & $( \pm 3.1)$ & $1.3( \pm 0.1)$ & 158 \\
\hline 1997 & $100 \quad( \pm 0)$ & $2.7 \quad( \pm 0.1)$ & $115( \pm 8.2)$ & 37 & $( \pm 6.8)$ & $1.3( \pm 0.2)$ & 127 \\
\hline 1998 & $97 \quad( \pm 2.9)$ & $2.2( \pm 0.1)$ & $136( \pm 8.1)$ & 103 & $( \pm 6.2)$ & $0.9 \quad( \pm 0.2)$ & 51 \\
\hline \multicolumn{8}{|l|}{$\mathrm{V} 2$} \\
\hline 1996 & $10.0( \pm 5.8)$ & $0.15( \pm 0.07)$ & $187( \pm 4.1)$ & 19 & $0 \quad( \pm 0)$ & $( \pm 0)$ & 37 \\
\hline 1997 & $4.2( \pm 4.2)$ & $0.04( \pm 0.04)$ & $172( \pm 6.6)$ & 21 & $1.4(1.4 \pm)$ & $0.01( \pm 0.01)$ & 121 \\
\hline 1998 & $26.8( \pm 8.8)$ & $0.32( \pm 0.13)$ & $170( \pm 5.9)$ & 22 & $10 \quad( \pm 7.0)$ & $0.10( \pm 0.07)$ & 55 \\
\hline
\end{tabular}

-0.42 for 1996,1997 and 1998 , respectively and -0.36 when all shoots from the years 1996-1998 were included in the analysis. The correlation was significant $(\mathrm{P}<0.05)$ only for 1998 and for the analysis including all years. However, no uninfested shoots were included in the correlation analyses for 1996 and 1997.

\section{Dry matter yields}

In V1, the dry matter yields dropped markedly in 1996, when the midge-infestation was first noticed and they continued to decline in 1997 and 1998 (Fig. 1). For all the years 19961998, the yields dropped significantly more $(\mathrm{P}<0.05)$ in spring-harvested compared to autumn-harvested plots and more in plots receiving $100 \mathrm{~kg} \mathrm{~N}$ compared to those receiving 200 $\mathrm{kg} \mathrm{N} \mathrm{ha}{ }^{-1}$ per year. The relative yields in 1998 was 46.9 for spring-harvested and 59.2 for autumn-harvested plots, crossed over nitrogen fertilisation treatments. For nitrogen fertilisation at $100 \mathrm{~kg} \mathrm{~N} \mathrm{ha}^{-1}$ per year, the relative yield in 1998 was 47.1 while the corresponding figure for 200 $\mathrm{kg} \mathrm{N}^{-1}$ was 59.0 , crossed over harvest times. There was no significant interaction between harvest time and nitrogen fertilisation.

For V2, with only a slight midge-infestation, only yield data from 1995-1998 are available. The yield in V2 was $19 \%$ lower than in V1 in 1995, before midge-damage occurred. Thereafter yield in V2 declined much less than in V1 (Fig. 1) such that yield in 1998 was $76 \%$ higher in V2 than in V1 (comparison of plots with the same nitrogen fertilisation and harvest time).

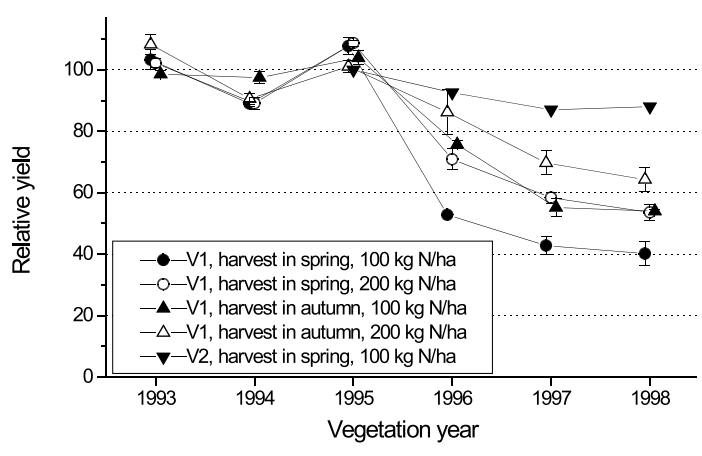

Fig. 1. Relative dry matter yields in field experiments with reed canary grass in Vojakkala for the years 1993-1998. The field V1 was severely infested by the gall midge Epicalamus phalaridis from 1996 onwards while V2 was only slightly infested.

The average dry matter yields in the years 1993-1995 (representing the value 100 in the figure) were: V1, harvest in spring, $100 \mathrm{~kg} \mathrm{~N} / \mathrm{ha:} 8869$ $\mathrm{kg} / \mathrm{ha}$; V1, harvest in spring, $200 \mathrm{~kg} \mathrm{~N} / \mathrm{ha}: 8484 \mathrm{~kg} / \mathrm{ha}$; V1, harvest in autumn, $100 \mathrm{~kg} \mathrm{~N} / \mathrm{ha:} 10969 \mathrm{~kg} / \mathrm{ha}$; V1, harvest in autumn, $200 \mathrm{~kg} \mathrm{~N} /$ ha: $12205 \mathrm{~kg} / \mathrm{ha}$;V2, harvest in spring: $7766 \mathrm{~kg} / \mathrm{ha}$ (yield data only available for 1995-1998). Error bars indicate standard error of the mean. 
Hellqvist, S. et al. Reed canary grass and effects of gall midge infestation

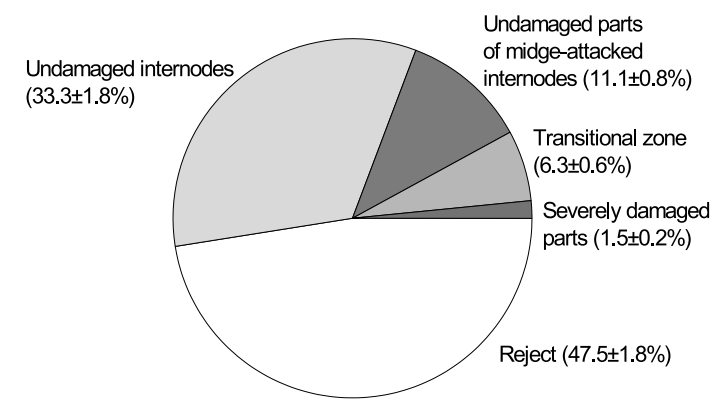

Fig. 2. Fractionation of spring-harvested reed canary grass from a crop severely infested by the gall midge Epicalamus phalaridis. Weight percent $\pm \mathrm{SEM} ; \mathrm{n}=3$. The different fractions (except reject fraction) were then analysed for fibre quality according to Table 2 .

The measured dry matter yields include not only reed canary grass but also weeds harvested at the same time. In V1, RCG was estimated to constitute more than $95 \%$ of the standing crop until 1995. Thereafter the occurrence of weeds like Epilobium angustifolium, Urtica dioica and Elymus repens gradually increased. By 1998, the proportion of RCG in the standing crop in autumn-harvested plots had decreased to $40 \%$ $(\mathrm{SEM}=15 ; \mathrm{n}=3)$ and $57 \%(\mathrm{SEM}=5 ; \mathrm{n}=3)$ in plots receiving 100 and $200 \mathrm{~kg} \mathrm{~N} \mathrm{ha}^{-1}$, respec- tively. In V2, RCG was estimated to constitute $90 \%$ of the standing crop throughout the period.

\section{Fibre quality}

Of the plant material from the crop with only very slight midge-infestation, $45.7 \%$ (SEM = $1.0 ; \mathrm{n}=3$ ) was classified as reject and the remaining part as undamaged internodes. Material from the midge-infested field was fractionated according to Fig. 2. The first impression of the midge-infested dried crop was that infested parts were very brittle and did not seem to contain much fibrous material. This was confirmed by the fibre analysis (Table 2). The pulp yield from fraction IV (severely infested parts) was only $40 \%$ of the pulp yield from fraction I (internodes from uninfested crop). Fraction IV had shorter fibres and contained much more fines than fraction I. Short fibres and a high amount of fines indicates that the pulp will have poor drainage properties and low strength properties. Consequently, severely damaged parts of midgeinfested internodes give a pulp with poor fibre properties. In contrast, the fibre properties of uninfested internode parts (fraction II and III) from the midge infested crop were in all respects

Table 2. Pulp properties of reed canary grass infested by Epicalamus phalaridis. Mean values $\pm \mathrm{SEM} ; \mathrm{n}=3$.

\begin{tabular}{|c|c|c|c|c|c|}
\hline Fraction & Pulp yield, & $\begin{array}{c}\text { Arithmetic } \\
\text { average length, } \\
\mathrm{mm}\end{array}$ & $\begin{array}{c}\text { Length } \\
\text { weighted } \\
\text { average, } \\
\text { mm }\end{array}$ & $\begin{array}{l}\text { Coarseness, } \\
\mathrm{mg} \mathrm{m}^{-1}\end{array}$ & $\begin{array}{c}\text { Fines } \\
(<0.20 \mathrm{~mm}), \\
\%\end{array}$ \\
\hline $\begin{array}{l}\text { I. Internodes from } \\
\text { uninfested crop }\end{array}$ & $56.2 \pm 0.7$ & $0.47 \pm 0.01$ & $1.09 \pm 0.01$ & $0.07 \pm 0.01$ & $29.2 \pm 0.9$ \\
\hline $\begin{array}{l}\text { II. Undamaged internodes } \\
\text { from midge-infested crop }\end{array}$ & $56.9 \pm 0.8$ & $0.47 \pm 0.02$ & $1.04 \pm 0.05$ & $0.07 \pm 0.01$ & $26.3 \pm 1.6$ \\
\hline $\begin{array}{l}\text { III. Undamaged parts of } \\
\text { midge-infested internodes }\end{array}$ & $55.4 \pm 0.9$ & $0.47 \pm 0.02$ & $1.10 \pm 0.03$ & $0.07 \pm 0.01$ & $28.8 \pm 2.1$ \\
\hline $\begin{array}{l}\text { IV. Severely midge- } \\
\text { damaged parts }\end{array}$ & $23.5 \pm 0.6$ & $0.25 \pm 0.02$ & $0.72 \pm 0.02$ & $0.14 \pm 0.02$ & $59.6 \pm 2.9$ \\
\hline $\begin{array}{l}\text { V. Transitional zone } \\
\text { between damaged and } \\
\text { undamaged parts }\end{array}$ & $46.5 \pm 0.8$ & $0.39 \pm 0.02$ & $0.96 \pm 0.05$ & $0.07 \pm 0.00$ & $39.3 \pm 1.3$ \\
\hline
\end{tabular}


Vol. 12 (2003): 49-56.

equal to those of internodes from the uninfested crop. The fibre properties of fraction V (transitional zone between damaged and undamaged parts) were intermediate between fraction III and IV.

\section{Discussion}

The RCG stand deteriorated markedly in a field severely infested by $E$. phalaridis during three consecutive years. As midge larvae infested all plots in the field, no comparisons between infested and uninfested plots in the same field can be made. It is possible that the dramatic drop in yield and the weakening of the RCG stand can have other causes than attack from E. phalaridis. We do, however, believe that the midgeinfestation is the major cause of the decline in yields. The yields varied much less in the slightly midge-infested field in Vojakkala and the two fields received similar amounts of fertilisation and experienced the same weather conditions.

Harvest in late autumn is not realistic when RCG is grown for industrial purposes (Burvall 1997, Hadders and Olsson 1997). However, data on yields after harvest in autumn are here included as they give a better measure of RCG productivity. With spring-harvest, there may be a substantial yield loss (Hadders and Olsson 1997). The yields in the midge-infested field dropped more when the crop was harvested in the spring than when it was harvested in the autumn. A plausible explanation is that a lodged, midge-infested crop, will be more compacted by the snow cover during the winter and thus more difficult to harvest properly in the spring. Also, as midge-infested shoots easily break into smaller pieces, it is likely that more straw material would be left in the field. The yield drop in V1 also was more pronounced in plots receiving 100 $\mathrm{kg} \mathrm{N} \mathrm{ha}{ }^{-1}$ compared to those that were fertilised with $200 \mathrm{~kg} \mathrm{~N} \mathrm{ha}{ }^{-1}$. A reason could be that if more nitrogen is available, more sterile shoots might emerge during the summer. These shoots escape midge-attack because they emerge later and they may continue to grow after damaged shoots have lodged.

Fertile shoots were considerably shorter in the severely midge-infested field compared to shoots in the less infested field, indicating that midge-infestation affects the shoot length. This was also confirmed by the correlation analysis that showed a negative correlation between number of midge-infested internodes and shoot length. However, the correlation was weak and direct effects of midge damage do probably not explain all the difference in shoot-lengths between the two fields. The short shoots observed in the heavily infested field may also partly be due to a delayed effect of infestation in the previous year. Midge-caused lodging of the shoots in late summer may hamper translocation of nutrients and carbohydrates from shoots to rhizomes in the autumn, resulting in weakening of the RCG stand. For the plant, a serious midgeinfestation may have similarities with a harvest in August. Field experiments have shown that if RCG is harvested in August in Northern Sweden, it results in a progressive weakening of the crop and a gradual increase in the occurrence of weeds (Landström et al. 1996).

The fibre properties of uninfested internode parts from the midge-infested crop were similar to those of internodes from the uninfested crop while midge-damaged parts produced a pulp with poor properties. Reed canary grass to be used by the pulp industry has to be pre-treated by dry fractionation. In the fractionation process, brittle parts of the plant are removed (Finell et al. 2000). As midge-infested parts of the straw are very brittle, these parts would probably be removed in the fractionation process. A midge-infested crop may thus still be used by the pulp industry. However, fractionation of a midge-infested crop would yield a lower percentage usable material. Another problem is that the occurrence of weeds in the field may increase after several years of serious midge attack. The harvested crop may then become contaminated with material from other plant species. To what extent such material affect pulp properties or can 
Hellqvist, S. et al. Reed canary grass and effects of gall midge infestation

be sorted out during a fractionation process is still unknown.

In 1997, when the numbers of midge larvae were counted on some shoots, as many as 3000 newly hatched larvae were found on single internodes, a figure that probably represents more than 30 oviposition events on a single leaf. A single internode can, however, not support such a high number of larvae and a maximum of about 700 mature larvae were recorded on single internodes later in the season. The drop in numbers of larvae noticed between early July and mid August was probably largely due to mortality caused by intraspecific competition. It was also observed that the size of larvae on over-crowded internodes was considerably smaller than normal.

The outbreak of E. phalaridis is so far a local phenomenon. It is only in Vojakkala where the gall midge has been found on cultivated RCG, and only in one field has the population density soared to an outbreak level. RCG is still only cultivated to a limited extent (about 1000 ha in Sweden), but because E. phalaridis has been found on several RCG stands in natural vegetation, a further spread to cultivated crops is expected if the cultivated area increases. It remains to be seen whether it will also occur at such high population level as reported here, in other fields. The deterioration of the RCG stand in the field in Vojakkala, however, indicates that E. phalaridis has potential to become a serious pest of RCG.

Acknowledgements. The Swedish Farmers' Foundation for Agricultural Research, NUTEK and Vattenfall provided financial support for this study. We would like to thank Calle Nilsson, Ulla Bång and two anonymous referees for valuable comments on the manuscript.

\section{References}

Barnes, H.F. 1946. Gall midges of economic importance. In: Gall midges of fodder crops. Vol. II. Crosby Lockwood \& Son Ltd, London. p. 119-120.

Burvall, J. 1997. Influence of harvest time and soil type on fuel quality in reed canary grass (Phalaris arundinacea L.). Biomass and Bioenergy 12: 149-154.

Finell, M., Hedman, B. \& Nilsson, C. 2000. Effect of dry fractionation on pulping conditions and fibre properties of reed canary grass. In: Kennedy, J.F. et al. (eds.). Cellulosic pulps, fibres and materials. Proceedings of the 10th international cellucon conference, 14-17 December 1998, Turku, Finland. Woodhead Publishing Ltd. p. 261-266.

Hadders, G. \& Olsson, R. 1997. Harvest of grass for combustion in late summer and in spring. Biomass and Bioenergy 12: 171-175.

Landström, S., Andersson, S., Hagsand, E. \& Luik, H. 1982. Temperatur och nederbörd vid de norrländska försöksstationerna 1962-1980. Röbäcksdalen Meddelar 1982 (1). $13 \mathrm{p}$.

Landström, S., Lomakka, L. \& Andersson, S. 1996. Harvest in spring improves yield and quality of reed canary grass as a bioenergy crop. Biomass and Bioenergy 11: 333-341.

Olsson, R., Torgilsson, R. \& Burvall, J. 1994. A new concept for reed canary grass production and its combined processing to energy and pulp. In: Non-wood fibres for industry, 23-24 March 1994, Silsoe, UK. Conference proceedings. Leatherhead, UK: Pira International. Paper 6. 8 p.

Paavilainen, L., Tulppala, J., Finell, M. \& Rehnberg, O. 1999. Reed canary grass pulp produced on mill scale. In: TAPPI pulping conference, 31 October - 3 November 1999, Orlando, FL, USA. Conference proceedings. Atlanta, GA, USA: TAPPI Press. p. 335341.

Saijonkari-Pahkala, K. 2001. Non-wood plants as raw material for pulp and paper. Agricultural and Food Science in Finland 10, Supplement No 1. 101 p.

Sylvén, E., Hellqvist, S., Sellerholm, G. \& Tastas-Duque, R. 1997. A new gall midge (Diptera: Cecidomyiidae), feeding beneath leaf sheaths of Phalaris arundinacea (Poaceae). Entomologisk Tidskrift 118: 99-109.

Tomaszewski, W. 1931. Cecidomyiden (Gallmücken) als Grasschädlinge. Arbeit aus der Biologischen Reichsanstalt für Land- und Forstwirtschaft 19: 1-15.

Vasarainen, A., Hannukkala, A. \& Grahn, J. 1999. Pests and diseases of reed canary grass, Phalaris arundinacea (L.). In: Workshop alternative crops for sustainable agriculture, 13-15 June 1999, Turku, Finland. COST 814 Crop development for the cool and wet regions of Europe: Program and abstracts. p. 2728. 